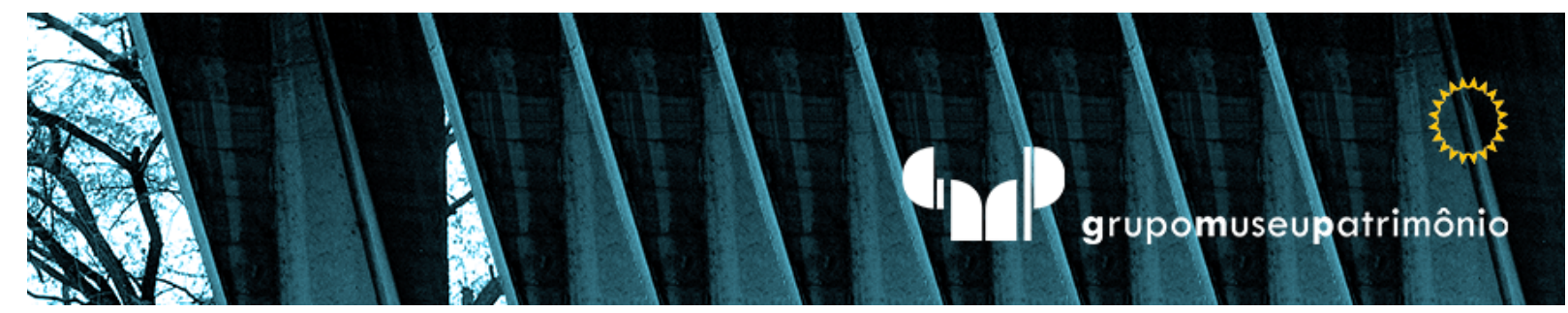

Editorial

\title{
O que ficará amanhã como patrimônio deste tempo, dominado por - espaços em movimento?
}

What will be tomorrow like heritage, this time world dominated by - moving spaces?

¿Qué restará mañana como patrimônio deste tiempo dominado por espacios en movimiento? 


\section{Resumo}

O Editorial ressalta a importância de debate crítico sobre a atualidade, realizado por distintas modalidades. Entre estes questionamentos se encontram os constituídos por imagens, formas e palavras; instituições culturais; ações no espaço urbano, na fricção entre áreas voltadas ao sensível. Inicia-se com a pergunta: "O que ficará amanhã, como patrimônio deste tempo, dominado por - espaços em movimento"? Parcela dos debates aqui congregados comporá patrimônio, este entendido como conjunto de valores, caros ao período e capazes de representar esta era.

Palavras-Chave: Espaço. Movimento. Patrimônio. Representação. Editorial.

\section{Resumen}

El Editorial subraya la importancia del debate crítico sobre el presente, realizado por diferentes modalidades. Entre estos questionamentos se encontran os que se componen de imágenes, formas y palabras; instituciones culturales; acciones en el espacio urbano, la fricción entre las zonas sensibles. Comienza con la pregunta: "¿Qué será mañana, como esta vez dominada por herencia - espacios en movimiento"? Parte de las discusiones aquí hará patrimonio, esto entendido como un conjunto de valores, estimados para el período y capaces de representar esta era.

Palabras clave: Espacio. Movimiento. Patrimonio. Representación. Editorial.

\section{Abstract}

The Editorial stresses the importance of critical debate about the present, performed by different modalities. Among these questions are those composed of images, shapes and words; cultural institutions; actions in urban space, the friction between the sensitive areas. Starts with the question: "what will be tomorrow, as this time dominated by heritage - moving spaces"? Portion of the discussions here will make heritage gathered together as a set of values, precious to the period and able to represent this era.

Keywords: Space. Movement. Heritage. Representation. Editorial. 


\section{ROMPER COM O EXÍLIO}

Sempre soube que as grandes surpresas nos esperam ali onde tivermos aprendido por fim a não nos surpreender com nada, entendendo por isso não nos escandalizarmos diante das rupturas da ordem. Julio Cortázar (1993, p.179)

V ivemos em momento estelar para se apartar do insulamento na própria terra, ou surpreender-se com rupturas da ordem, como bem alude o escritor argentino Julio Cortázar (1914-84). Este, descontente com o rumo político em seu país, já em 1951, partiu para Paris com bolsa de estudos e nunca mais retornou. Em inúmeros depoimentos relembrou a infância povoada por personagens, tempo e espaço também distintos, porquanto lia muito, quando esteve doente e incapaz de se mover como as demais crianças.

Exponho com satisfação o conjunto desta Revista ARA, de número quatro, com a temática Espaços em movimento. Resultou em conjunto significativo graças aos membros do Grupo Museu/Patrimônio [GMP], ao Conselho Editorial/CE, aos colaboradores e ao apoio da Faculdade de Arquitetura e Urbanismo da 
Universidade de São Paulo, FAU/USP. Por certo contribuirá para se renovar a esperança de aprimoramento e se encorajar leitores para circular por outros caminhos, para além do círculo diário com que convivemos. Deseja-se modificar a sensação de exílio, diáspora, ausência de perspectivas e penumbra que paira no ar e alçar à surpresa, em várias latitudes.

Neste século XXI incidem impactos, quando imaginávamos não mais ser espantados por diversos impasses, situações, instantes e circunstâncias bizarras. Consecutivamente, germinam-se novos choques, diante de flagelo, entraves, descontinuidade, violência, rapidez, submissão, singeleza, entre tantos outros aspectos, que seguem ensejando assombro ante a ausência de propalada humanidade a sobressaltar o cotidiano. Urge como nunca contrariar nefastas forças imobilizadoras e superar o individualismo autorreferente.

A Revista ARA surgiu como empenho para se rever o clichê e em busca de não referendar ações corporativas voltadas à auto preservação, disputa por poder entre membros de comunidades, ou abrigo a verdades postulares e dominadas por um estreito segmento, por considerar essas ações obstáculos a câmbios. Ressalte-se também que, ao ser projetada, surgiu de sonho coletivo viabilizado pelo Grupo Museu Patrimônio, com troca de atuações e tarefas entre os membros. Alargado em seu anseio, cada vez mais envolve novas narrativas e campos, em esforço conjugado para tentar desbordar fronteiras, ampliar questões e interlocutores em áreas e modalidades abalizadas.

Desde o número inicial há uma interdisciplinariedade de enfoques, demandas e aceitação da diferença, como algo desejável. Enfim, sempre procuramos romper com as certezas e expor-nos à crítica, extrovertendo pesquisas, a que todos nós nos dedicamos, reunidas aqui no chamado "Dossiê GMP". O foco são problematizações contemporâneas, como convite a debater ângulos inéditos e fora do mercado cultural, posição defensável e rara, abrigada em estudos universitários, na área de extensão cultural.

No entanto, considera-se importante interrogar este tempo, palavra esta que em tupi guarani se enuncia como ARA -, com viso crítico, sem se mergulhar em 
intenso exílio ante o entorno e o sentido humano. Assim, a postura demanda abrir rotas radiantes, destemidas e criativas, como se observa em imagens e textos ao longo desta edição. Após os Anos 1960, a concepção e a visualidade romperam com as formas apenas belas, contemplativas, inovadoras, a causar êxtase e maravilhamento. Imagens e palavras aqui enlaçadas aprofundam problemas desta era, enfim, o que se legará às próximas gerações, sem apenas reproduzir peculiaridades edificantes, ou versão ingênua de enredos veiculados em mega mídias comunicacionais.

\section{Temas, tempo e espaço em movimento.}

Os temas, por compreensiveis razões estratégicas, tornam-se mais imediatos no tempo e no espaço. Julio Cortázar (1993, p.63)

Os temas de cada edição da Revista ARA fundam-se na época presente com viés crítico e ênfase nos dedicados às áreas sensíveis e transdisciplinares, sendo investigados e propostos pelo GMP. Compete ao Conselho Editorial selecionar uma entre as opções indicadas e eleger, para cada colaboração, o mínimo de dois especialistas para realizar parecer denominado "às cegas", ou seja, sem revelar a autoria, evitando preconceito, ou melhor, como se expressa na língua inglesa - prejudice.

Nesta edição se documenta, em distintos formatos, como tantos buscam reagir em relação a descaminhos desta época. Desvelam como hoje pode se construir novos sonhos, desafios, pactos, caminhos, desvios e dialogar com a alteridade, ou seja, aprender com a diferença e evitar apenas desqualificá-la. Com perplexidade, assiste-se a levas e levas de humanos cruzando fronteiras, mares e territórios, em ritmo contrastante com outras realidades. Seriam tais situações o patrimônio a ser erigido sobre o segundo decênio deste século?

As mídias digitais instituem outra hipótese para nos representar amanhã, com vários ângulos, entre os quais: de um lado mudou práticas cotidianas, com 
proveito; e, de outro, veiculou como nunca falsos informes, desabono a pessoas e fatos. Dissiminam-se, como um vírus, dados duvidosos em proveito próprio, ou apenas por mero entretenimento torpe. De maneira veloz e singular, as redes estampam certezas programadas, para que cada um se mantenha em seu próprio quadrilátero de conforto e valores, sem enfrentar desafios. Estes se tormarão nossa imagem futura, se não desaparecerem os atuais meios, diante de novos com as quais não se relacionariam? Como hoje se pode ver aqueles microfilmes? Em que aparelhos e lugar?

Em contraste com a atualidade, durante as Luzes muito se predicou sobre a necessidade do artista se afastar de temas críticos e, ao contrário, exaltar o belo. O criador parecia flanar acima dos mortais, porquanto permanecia a postura renascentista de nomeá-lo por 'gênio divinal'. Como decorrência, ainda na atualidade mantem-se tal postura, entendendo as instituições como destinadas a salvaguardar os 'tesouros', erigidos pelo engenho de poucos eleitos, como mera função conservacionista e veiculadora de saber, antes de mais nada para pares letrados. Até quando?

O célebre escrito de 1766, elaborado por Gotthold Ephraim Lessing (1729-81) sobre a escultura localizada em 1506 "Laocoonte", no capítulo 9 condena perempetoriamente poetas e artistas que não tenham podido produzir o belo livre de coação externa, seja pela religião ou poder. Pensando talvez nesses tesouros da Igreja Católica, muitas vezes espoliados de inimigos e com tema exógeno, em face da tal intenção do artista, Lessing documenta o lugar que a dita beleza ainda ocupava. Vale sublinhar que à época dos escritos de Lessing poucas eram as instituições abertas ao público em geral e, mesmo o Museu do Louvre/Paris apenas será instituido mais de vinte anos depois, em 1789. Acrescente-se que, facultado ao ingresso de todo e qualquer espectador como hoje se constata, demorará quase um século para se efetivar. 


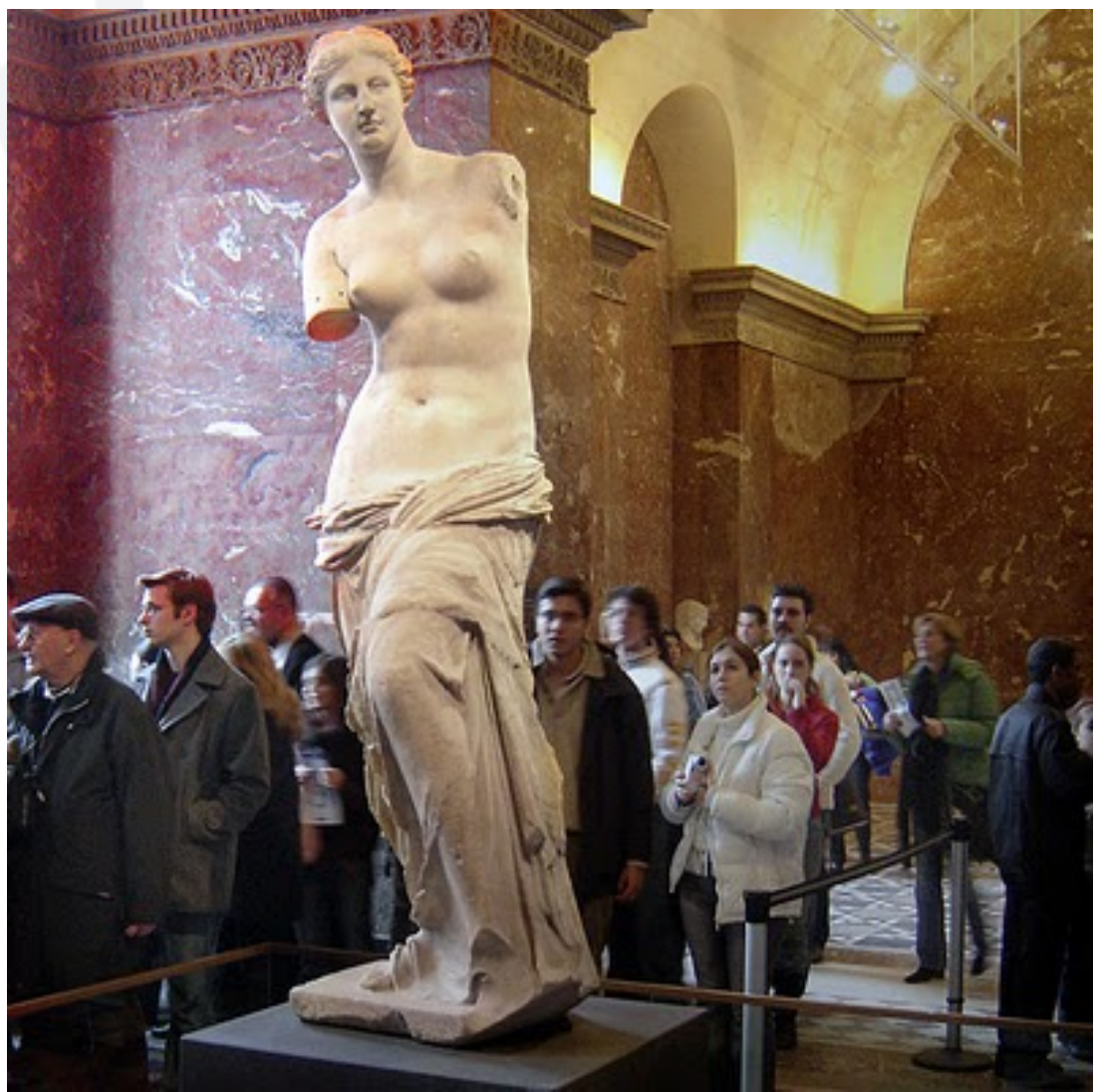

Figura 1 -Vênus de Milo. Museu do Louvre, c. Século Il a.C. Foto autora 2010

O caso da escultura denominada Laocoonte, analisada por vários autores, foi localizada na Coleção Vaticano e, após as querelas religiosas, foi exposta ao público, assim reafirmando o poder e a reserva de saberes determinados. Talvez por tais circunstâncias, o pensador alemão preferiu reservar o nome de 'obra de arte' "[...] apenas para aquelas [...] nas quais a beleza constituía sua primeira e última intenção" (Lessing, 1998, 153 [1766]).

O tema ligado à mitologia de um mundo pagão acolhido na sede do catolicismo teria ficado por portar testemunho irredutível do belo. Nas discussões daquele momento, século XVIII, a superioridade da poesia, com predomínio da palavra, se alçaria ou não sobre as demais artes? Assim, Lessing concordará com outros sobre a tese de que a boca entreaberta da personagem revela o momento fundante da dita obra prima, mantida em espaço díspar ao 
que se originou, para além de mero troféu conquistado pela sujeição de estados, pensamentos e religiões.

Como se pode constatar, o conjunto de imagens, textos e reflexões desta edição desgarçou as formas habituais em que se abordam museus, patrimônio, meio urbano, monumentos, fotografia, arte, arquitetura, exposição, ocupação, cidade digital, interface, novas mídias, arte on-line, contracolecionismo e instituições preservacionistas, ensejando dúvidas para cada um refletir conforme considere como abertura para atalhos singulares.

O conjunto, que com enorme satisfação apresentamos, abrange amplo território, desde o país, a América Latina até a Europa. Entre as questões subjacentes versa também sobre cidadania; espaço vivenciado; prática espacial crítica; espaço público; renovação urbana; espaços interativos; narrativas; inquietações rugosas; autonomia do campo museal versus negócios; urbano e rural; campos em fricção; territórios; mobilidade física; fluxos e fixos; sistemas de objetos, ações e sociais; circulação de imagens; museu imaginário e Instagram.

Aguardamos diálogo, questionamentos e contribuições, deixando assinalado profundo agradecimento a todos que se dispuseram a aprimorar, aprofundar, debater, afirmar ou retificar pontos de vista, como temos tentado fazer. Boa leitura e aguardamos desde já as inquietações de diversificados colaboradores, em ensaios poéticos, de texto, fotografia, desenho, ou qualquer outra forma gráfica que trabalhe sobre o tema determinado para a quinta edição da Revista ARA - Configuração entre limites e inderminação.

Ciça, verão, 2018.

\section{BIBLIOGRAFIA CITADA}

Cortázar, Julio. Valise de Cronópio. 2 ed. São Paulo, Perspectiva, 1993.

Lessing, Gotthold Ephraim. Laocoonte: ou sobre as fronteiras da pintura e da poesia. São Paulo: Iluminuras, 1998. 